\title{
Instructional Delivery and Students' Experiences with Distance and Online Learning of Undergraduate Mathematics in Nigeria
}

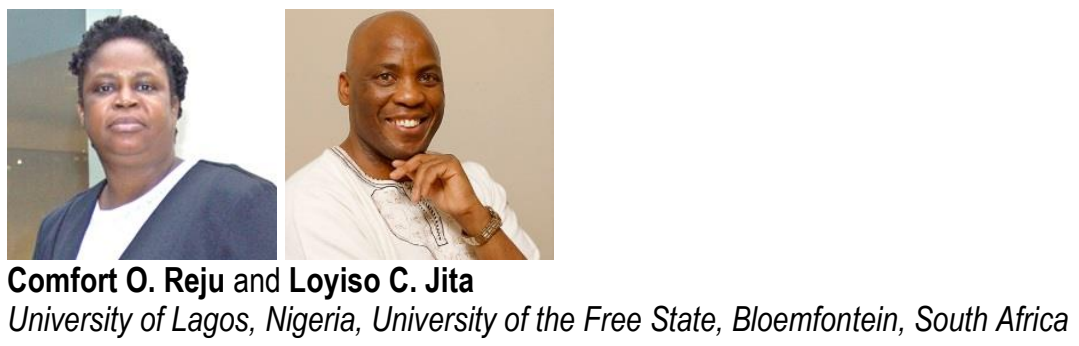

\begin{abstract}
This paper examines the students' experiences with instructional delivery (ID) of distance and online learning of undergraduate mathematics in two major Nigerian universities. Purposive sampling was used in the study to select mathematics students from University of Lagos Distance Learning Institute (DLI) and the National Open University of Nigeria (NOUN). Data were collected through mixedmethods and a one-sample binomial test was employed to analyse the quantitative data. Furthermore, narrative and content analyses were done to explore how respondents make sense of their experiences of learning mathematics through the distance and online mode. Among others, the results of the study suggest that the abstract nature of mathematics was not appropriately addressed in the course content and that the absence of helpful and visible tutors for the subject complicated the challenge of understanding abstract mathematics even further. Among the many challenges, the abstract nature of mathematics and the absence of qualified tutors points to the need for improvement in the design, development, and provision of mathematics course materials and programmes for distance and online mathematics learning.
\end{abstract}

Keywords: instructional delivery, distance and online learning, undergraduate mathematics 


\section{Introduction}

In recent years, distance and online learning have become major topics in education, in part because of their increasing popularity as a means for broadening access to higher education for many students (Tapfumaneyi, 2013). Where many universities and colleges are creating more online and distance education programmes, the original single mode Open and Distance Learning (ODL) institutions are expected to be leaders in instructional design (ID). New challenges are also emerging, such as how ODL institutions can enhance their distance and online delivery in an environment that is becoming more and more diverse, thus creating new areas for research investigation (Bertini, 2016). Prior studies have identified lack of instructors' competence to deliver quality instruction to establish meaningful educational experiences for the learners as one of the basic barriers of distance and online learning (Harrington \& Loffredo, 2010). The overall aim of this paper is to examine students' experiences in ID in an undergraduate mathematics course at two ODL universities in Nigeria.

The quality of educational provision in most distance and online learning institutions remains a concern despite an increase in the use of online tools (Jones \& Long, 2013). According to Evrim, Correia, and Thompson, (2011), students enroll in distance and online mathematics with varied experiences which affect their views and methods of approaching the subject. The traditional approaches to distance and online delivery have not contributed much to success in mathematics courses and programmes, something which has led to the introduction of more multimedia tools for distance and online services and tutorials to improve access and success in these gateway subjects (Juan, Huertas, Steegmann, Corcoles, \& Serrat, 2008; 2008; Yushau \& Khan, 2014). Surprisingly, most studies on distance and online ID have not focused on mathematics students' experiences, especially at the university-level (Mayes, 2011; Jones \& Long, 2013). This paper helps to contribute to the literature on ID and students' mathematical experiences at the university-level, particularly within the ODL environment.

The growth witnessed in distance and online education worldwide has affected distance and online learning of mathematics positively, and hence, driven the revision of ID in institutions of higher learning. However, there is still a gap in our understanding of students' experiences with ID in distance and online learning of undergraduate mathematics. In this paper, we discuss ID in an ODL environment and its effect on students' experiences of learning university-level mathematics using the Nigerian ODL context as our focusi. We will then provide answers to the following questions, specifically:

1. How does the use of ID through course materials affect students' experiences in distance and online learning of undergraduate mathematics?

2. How can undergraduate mathematics students' experiences with ID be understood and/or explained?

3. What are the possible proposals to enhance ID and students' experiences with distance and online learning of undergraduate mathematics?

\section{Background}

The increasing adoption of distance and online learning is considered a major and fundamental educational advancement in Nigeria (Osipita, 2016). Information and Communication Technology (ICT) was interestingly included in the policy guidelines establishing distance and online learning in 
Nigeria (Federal Republic of Nigeria, 2004). It was recommended that ICT should be used in ID of ODL academic programmes and students should have adequate access to it. However, there is no plan on how ICTs will be made available for both the learners and ODL institutions. The Distance Learning Institute (DLI) of University of Lagos (a dual mode), and the National Open University of Nigeria (NOUN; a single mode), are two of the designated ODL institutions in the country. The aim of designating these universities was to provide opportunities to people who cannot get away from their work for full-time, conventional learning (Jimoh, 2013). These institutions primarily employ print materials in delivery of instruction to the students and are presently and actively using online resources (Garrett, 2016). Notwithstanding the improvements observed in the using of online resources in Nigeria, their impact on the distance and online learning of mathematics specifically are yet to be established. This is not entirely consistent with the mission and vision delivery of ODL in Nigeria. In view of this, a gap is created in the learning of mathematics through this mode.

Tapfumaneyi (2013) examined the contribution of ODL as a catalyst for social, economic, and sustainable development in Africa. The study identified "hard science (mathematics inclusive) progammes as too "practical" to be offered through the ODL mode of delivery" (p. 563). Some other available studies have shown that when ID is well-structured with the new technological tools, it provides more effective experiences than is obtainable in face-to-face classroom learning (Jimoh, 2013; Jones \& Long, 2013). Nevertheless, some researchers have identified lack of consistency in policy implementation, lack of instructors, and poor developed instructional materials as problems affecting distance and online ID in Nigeria (Osipita, 2016; Edu, Sule, \& Nsor, 2016). Distance and online education system in Nigeria take the form of dual and single modes where print (course materials) and face-to-face interactions or classes are heavily relied upon and dominate the course delivery (Ayo, Odukoya, \& Azeta, 2014). Osipita (2016) also stated that "the distance education delivery system appears similar to traditional education because distance learners still need to attend classes irrespective of their places of residence and work" (p. 4). These cases demonstrate that the problems of ID with appropriate technology are not entirely solved in the distance and online systems of ODL in Nigeria. In view of these challenges, the present study sought to understand students' experiences of learning mathematics through this mode.

In Nigeria, DLI, though established in 1973, was accredited in 2008 as a dual-mode institution to offer distance and online education by a supervisory agency of university education-the National Universities Commission (NUC). The institution has its study centres spread within university of Lagos. NOUN on the other hand was approved in 2001 as a single-mode university and has its study centres located in different parts of Lagos and other locations in Nigeria. The students in these institutions register and attend the centres nearest to them. Both institutions (DLI and NOUN) offer mathematics education degree programmes to students who failed to secure admission to conventional institutions (Ayo et al., 2014). Academic activities such as application, admission, registration, result checking, and to some extent, learning, are done online. The process of learning involves students collecting the course materials from the institutions, studying and interacting with the facilitators either online or face-toface, and participating in organised weekend lectures and face-to-face examination (Edu, Sule, \& Nsor, 2016). One of the major problems facing ODL programmes in Nigeria is that its practices stem from conventional teaching and learning and ID application involves variations and copies of face-to-face methods of teaching and learning (Tapfumaneyi, 2013). Ohene and Essuman (2014) made assertion that course materials could, in some cases, constitute a barrier to distance and online learning if they are not specifically and well-modified for effective learning. It is against this background that this paper 
investigates current experiences of the students learning mathematics in both DLI and NOUN, to contribute to the scarce empirical research in this area in Nigeria.

\section{Conceptual Framework}

The conceptual framework is developed based on the purpose of this paper, and seeks to answer the question: What are the students' experiences with ID in an undergraduate mathematics course in Nigeria?

The Commonwealth of Learning (COL) maintains that one of the policies guiding distance and online delivery is that the teacher is replaced by mixture of course materials and instructors. They pointed out that it is expensive to engage instructors in learning activities aimed at meeting the learners' educational needs (Commonwealth of Learning, 2005). This shows that the instructional material should be able to carry out the task of an instructor to a reasonable extent. To achieve this, Ohene and Essuman (2014) advocate coordinated teamwork among instructional designers, educators, online media developers, and graphic designers, working together to create a good environment for learning. For the course materials to have an effective impact on students' experiences, the instructors should understand their needs while designing the materials.

Researchers have outlined characteristics of good instructors such as: communicating the delivery of content to the students; facilitating learning and supporting students learning, both academically and technologically; assessing students and giving quality feedback promptly; guiding and counselling students regularly in their study and private matters; and recognising the students uniqueness and autonomy in learning (Bertini, 2016; Hathaway, 2014). It has been shown in studies that these characteristics are not adequately seen in most of the distance and online instructors (Young \& Duncan, 2014). Therefore, it is very important to ascertain how the characteristics affect ID and students learning experiences in distance and online education.

Vilardi and Rice (2014) examined mathematics achievement in traditional instruction and technologyassisted course delivery methods. The results show that "students are learning in the technologyassisted classroom, but not at the same level as their traditional counterparts" (Vilardi \& Rice, 2014, p. 23). On the other hand, Jones and Long (2013) found in their study that there was no significant difference in the mean scores of students learning mathematics through on-site or online mode, thereby concluding the possibility of students achieving equity in mathematics while learning through the both modes. Research in ODL institutions in Nigeria indicate that the delivery is characterised with the use of manual, analog, and traditional methods (Ayo et al., 2014). This largely affects the delivery quality of mathematics through distance and online learning modes. However, the results of our study on students' experiences with ID in distance and online learning of mathematics in Nigeria specifically, provides empirical evidence of various challenges characteristic of ODL in Nigeria, especially in the delivery of hard sciences, taking mathematical literacy as a special case.

The foundation of the study is based on Experiential Learning Theory (ELT). The theory is chosen because of its emphasis on the interaction between the students and the learning environments. The assertion of the ELT (Kolb, 1984) is the idea that the process of learning is represented in a cycle of concrete experiencing, reflective observation, abstract conceptualisation, and active experimentation. Kolb stressed that students exhibit different preferences of learning within a cycle. 
The concrete experiences of students favour specific examples and learning support that allow peer group learning. These learners prefer receiving feedback from peers, hence, recognise their instructors as helpers. Reflective observation emphasises that a learner prefers observing before acting and relating with all available learning materials to be able to understand ideas and situations from different points of view (Kolb, 1984). Students in this cycle view instructors as experts and exhibit the habit of avoiding interaction with peers. The students at the abstract conceptualisation stage develop theories, conduct systematic close examination of situations, and theorise ideas for solving problems. This active experimentation advocates that learners are concerned with solving practical problems through group discussions, devising methods of evaluating situations, and are interested in what works (Kolb, 1984; Barker, Robinson, \& Kolb, 2012). It can be inferred that ELT presents a holistic model of the learning experience with students at the centre and supports a multi-lateral model of adult development that seems necessary for our paper (Kolb, Boyatzis, \& Mainemelis, 2000, p. 2).

The theory is learner-centred and allows students to manage and control their individual learning while the instructor facilitates the learning. It has been used as a framework by some researchers in ID a distance and online mode (Harrington \& Loffredo, 2010). The indicators expressed in this theory make it more helpful in exploring students' experiences in ID of mathematics at the university. However, there is very little research on ID using ELT as framework in distance and online education in Nigeria, hence, the choice of this theory in this study.

Distance and online students in different locations may need a different combination of experiences but the total experiences for every learner should be equal in value (Jones \& Long, 2013). Consequently, the students regulate their intellectual mind to adapt to new experiences. Experience is a continuously vital component in learning because it involves the learner deliberately using experiences. Carver, King, Hannum, and Fowler (2007) stated that experiential learning provides an already existing framework in which to develop a new model for online learning, featuring the individual either alone or in creative interaction. Emphases were made in the activities that lead to effective distance and online learning using affective, symbolic, perceptual, and behavioural learning environments. Murphrey (2010) speaking in favour of ELT opined that "one of the most important and powerful aspects of experiential learning is that the images in our brains come from the experience itself” (p. 213). It is necessary for ODL institutions to apply this theory in distance and online course delivery to advance the students learning experiences.

The relevance of ELT has made its application in generating data to answer the three questions raised in this paper necessary. The theory also guides the analysis and discussion of the findings.

\section{Methodology}

This paper examined students' experiences with ID in an undergraduate mathematics course at two ODL universities in Nigeria. The explanatory sequential mixed-method design as described in Creswell (2014) was employed to provide insights into the operation of two ODL institutions on undergraduate mathematics learning through distance and online programmes. This design provided for the collection and analysis of quantitative, followed by gathering and analysis of qualitative data. Consequently, the qualitative data in this study was used to complement and better interpret the results of the quantitative data. As a multiple case study, purposive sampling was used to select an informative sample of 60 third year mathematics education students at both universities (DLI $n=30$ and NOUN $n=30$ ). This purposive 
sampling method was used to ensure that only third year students studying mathematics in distance and online modes were selected. The motivation for using these category of students was because they have had two years of experience in the programmes and are not novices in administration of distance and online programmes in their institutions.

The instruments, largely closed-ended questionnaire with a limited number of open-ended questions, together with semi-structured interviews, were developed in which some aspects were in line with Ramsden's (1991) course experience questionnaire (CEQ). The instruments were revised and adjusted to suit Nigerian ODL systems and approval was obtained from appropriate university authorities. The questionnaire-formulated on a 5-point Likert scale of strongly agree, agree, neutral, disagree, and strongly disagree-was administered to DLI students on their centre meeting days which takes place once in two weeks; while a Short Message System (SMS) was used to invite NOUN students to complete the questionnaire since they did not have a specific day for centre meetings. Appropriate transport arrangements were made for the participants to facilitate our meetings. In addition to the questionnaire, a total of 10 students that completed the questionnaire in the two ODL institutions were conveniently sampled and interviewed. The interview questions were adapted from the core items of the questionnaire. This was done to obtain additional information regarding students' experiences with ID of mathematics in the ODL institutions studied. The interviews were recorded, with permission from the interviewees, for the purpose of capturing the participants own words for proper analysis. The participants were assured that their participation was voluntary and that there would be no penalty for withdrawal or non-participation.

The triangulation of quantitative and qualitative data helped to improve the reliability and validity of the results. The reliability coefficient of 0.72 was determined using Cronbach's alpha technique. In addition, a pilot study was conducted with mathematics students $(n=8)$ to test the survey (questionnaire) instrument and two of those students were also interviewed. The pilot results indicated that the students understood the questions and the key constructs of the study.

Mixed methods data analysis was done through a Parallel Analysis (PA) as proposed by Teddlie and Tashakkori (2009). This allows quantitative analysis to be conducted independently of the qualitative analysis. A one-sample binomial test was used to analyse the quantitative data because the data was fixed at $n=60$, the responses were independent of each other, and the data was ordinal. The qualitative data was transcribed word-for-word, coded to generate categories and subcategories, and thereafter themes were developed and analysed using the narrative approach (Elo \& Kyngäs, 2008).

\section{Results}

The results of the students' responses to each of the questions in this paper were explored. The number of the students that agree or disagree on each of the questionnaire items necessitated re-grouping the 5-point Likert scale into agree (consisting of strongly agree and agree; A), disagree (consisting of strongly disagree and disagree; D), and neutral (N). The interest was not whether or not the respondents agree to the items under consideration, but to understand how ID helps in shaping the mathematical experiences of the learners; and as a result the responses were dichotomised into agree and not agree leaving out those that were neutral. This allows for the binomial distribution in the non-parametric form to be considered appropriate for the analysis. The p-values were also used to establish whether the percentage responses of the participants were related. The results are presented in Tables 1 and 2. 
Table 1

Responses of DLI and NOUN Students as Related to Course Materials

\begin{tabular}{|c|c|c|c|c|c|c|c|}
\hline $\mathrm{N}$ & Questionnaire item & $\begin{array}{c}\mathrm{A} \\
(\%)\end{array}$ & $\begin{array}{c}\mathrm{D} \\
(\%)\end{array}$ & $\begin{array}{l}\mathrm{N} \\
(\%)\end{array}$ & $\mathrm{M}$ & SD & $\begin{array}{c}\text { B.T } \\
\text { (p-value) }\end{array}$ \\
\hline 1 & $\begin{array}{l}\text { The abstract nature of } \\
\text { mathematics is not simplified in } \\
\text { the design of the course } \\
\text { materials. }\end{array}$ & $\begin{array}{r}23 \\
(38.4)\end{array}$ & $\begin{array}{r}26 \\
(43 \cdot 3)\end{array}$ & $\begin{array}{r}11 \\
(18.3)\end{array}$ & 2.95 & 1.24 & .775 \\
\hline 2 & $\begin{array}{l}\text { I have access to course materials } \\
\text { online over the Internet. }\end{array}$ & $\begin{array}{r}45 \\
(75.0) \\
\end{array}$ & $\begin{array}{r}9 \\
(15.0) \\
\end{array}$ & $\begin{array}{r}6 \\
(10)\end{array}$ & 3.92 & 1.20 & .000 \\
\hline 3 & $\begin{array}{l}\text { The contents covered in the } \\
\text { mathematics course materials } \\
\text { are adequate for the period the } \\
\text { student is required to complete } \\
\text { the course work. }\end{array}$ & $\begin{array}{r}26 \\
(43 \cdot 3)\end{array}$ & $\begin{array}{r}19 \\
(31.7)\end{array}$ & $\begin{array}{r}15 \\
(25.0)\end{array}$ & 3.10 & 1.05 & .371 \\
\hline 4 & $\begin{array}{l}\text { ODL course materials in my } \\
\text { institution meet students' } \\
\text { mathematical and experiential } \\
\text { needs for personal mathematics } \\
\text { interest. }\end{array}$ & $\begin{array}{r}31 \\
(51.6)\end{array}$ & $\begin{array}{r}14 \\
(23.4)\end{array}$ & $\begin{array}{r}15 \\
(25.0)\end{array}$ & $3 \cdot 30$ & 1.06 & .017 \\
\hline 5 & $\begin{array}{l}\text { ODL course materials in my } \\
\text { institution meet students' } \\
\text { mathematical and experiential } \\
\text { needs for requirements for } \\
\text { degree award and certification. }\end{array}$ & $\begin{array}{r}48 \\
(80.0)\end{array}$ & $\begin{array}{r}3 \\
(5.0)\end{array}$ & $\begin{array}{r}9 \\
(15.0)\end{array}$ & 3.90 & 0.84 & .000 \\
\hline 6 & $\begin{array}{l}\text { I usually feel so bored when I } \\
\text { study mathematics concepts that } \\
\text { I quit before I finish what I } \\
\text { planned to cover in the course } \\
\text { material. }\end{array}$ & $\begin{array}{r}19 \\
(31.7)\end{array}$ & $\begin{array}{r}32 \\
(53 \cdot 3)\end{array}$ & $\begin{array}{r}9 \\
(15.0)\end{array}$ & 2.65 & 1.12 & .000 \\
\hline 7 & $\begin{array}{l}\text { When the mathematics course } \\
\text { material is difficult to } \\
\text { understand, I give up or study } \\
\text { only the easier parts. }\end{array}$ & $\begin{array}{r}17 \\
(28.3)\end{array}$ & $\begin{array}{r}34 \\
(56.7)\end{array}$ & $\begin{array}{r}9 \\
(15.0)\end{array}$ & 2.48 & 1.23 & .025 \\
\hline 8 & $\begin{array}{l}\text { Even when the mathematics } \\
\text { course materials are not } \\
\text { interactive enough, I manage to } \\
\text { continue working to understand } \\
\text { and finish them. }\end{array}$ & $\begin{array}{r}46 \\
(76.7)\end{array}$ & $\begin{array}{r}5 \\
(8.3)\end{array}$ & $\begin{array}{r}9 \\
(15.0)\end{array}$ & $3 \cdot 78$ & 0.92 & .000 \\
\hline
\end{tabular}

*Binomial test

Items 2,4 , and 5 with $\mathrm{p}<.05$ indicated that the provision of course materials is considered the lifeblood of ID for their degrees and certification. The findings are consistent with the results of previous studies by Lee (2014) and Ku, Akarasriworn, Glassmeyer, Mendoza, and Rice (2011) which indicated that students pay more attention when the online course materials are presented with clear guidelines and expectations. Item 8 with $(\mathrm{p}<.05)$ shows how determined and resilient the students are in learning in this mode. Furthermore, items 6 and 7 seemed to have significant biases, indicating students' persistence in learning mathematics through this mode. The preference in item 1 is more evenly spread (p-value well above 0.05), expressing no significant difference between those that agree and those that disagree. Hence, the result suggests that the abstract nature of mathematics is not completely dealt with in the design of the course materials. The p-value above 0.05 witnessed in item 3 shows existence of insignificant difference between the participants that agree and those that disagree. This indicates that 
the content of the course materials may not be explanatory enough to meet the participants' mathematical needs.

Table 2

Responses of DLI and NOUN on How ID Can be Understood and/or Explained

\begin{tabular}{|c|c|c|c|c|c|c|c|}
\hline $\mathrm{N}$ & Questionnaire item & $\begin{array}{c}\mathrm{A} \\
(\%)\end{array}$ & $\begin{array}{c}\mathrm{D} \\
(\%)\end{array}$ & $\begin{array}{c}\mathrm{N} \\
(\%)\end{array}$ & M & SD & $\begin{array}{c}\text { B.T } \\
\text { (p-value) }\end{array}$ \\
\hline 9 & $\begin{array}{l}\text { Learning mathematics through a } \\
\text { distance and online mode in my } \\
\text { institution is frustrating. }\end{array}$ & $\begin{array}{r}19 \\
(31.7)\end{array}$ & $\begin{array}{r}28 \\
(46.7)\end{array}$ & $\begin{array}{r}13 \\
(21.6)\end{array}$ & 2.82 & 1.37 & .243 \\
\hline 10 & $\begin{array}{l}\text { Many mathematical problems } \\
\text { cannot be solved through } \\
\text { distance and online learning. }\end{array}$ & $\begin{array}{r}33 \\
(55.0)\end{array}$ & $\begin{array}{r}22 \\
(36.7)\end{array}$ & $5(8.3)$ & 3.20 & 1.36 & .178 \\
\hline 11 & $\begin{array}{l}\text { I enjoy learning mathematics } \\
\text { through distance and online. }\end{array}$ & $\begin{array}{r}20 \\
(33.3)\end{array}$ & $\begin{array}{r}25 \\
(41.7)\end{array}$ & $\begin{array}{r}15 \\
(25.0)\end{array}$ & 2.83 & 1.30 & .551 \\
\hline 12 & $\begin{array}{l}\text { I have reliable access to Internet } \\
\text { for my school needs. }\end{array}$ & $\begin{array}{r}30 \\
(50.0) \\
\end{array}$ & $\begin{array}{r}15 \\
(25.0) \\
\end{array}$ & $\begin{array}{r}15 \\
(25.0) \\
\end{array}$ & 3.23 & 1.21 & .037 \\
\hline 13 & $\begin{array}{l}\text { The following can help to } \\
\text { improve the students' } \\
\text { experiences further in distance } \\
\text { and online learning of } \\
\text { mathematics in my institution: } \\
\text { Access to my mathematics } \\
\text { tutors/ lecturers. }\end{array}$ & $\begin{array}{r}50 \\
(83.4)\end{array}$ & $\begin{array}{r}5 \\
(8.3)\end{array}$ & $\begin{array}{r}5 \\
(8.3)\end{array}$ & 4.25 & 1.04 & .000 \\
\hline 14 & $\begin{array}{l}\text { The following can help to } \\
\text { improve the students' } \\
\text { experiences further in distance } \\
\text { and online learning of } \\
\text { mathematics in my institution: } \\
\text { Using different forms of media - } \\
\text { print, audio, video, etc. }\end{array}$ & $\begin{array}{r}50 \\
(83.3)\end{array}$ & $\begin{array}{r}6 \\
(10.0)\end{array}$ & $\begin{array}{r}4 \\
(6.7)\end{array}$ & 4.22 & 1.06 & .000 \\
\hline 15 & $\begin{array}{l}\text { Face-to-face remains the } \\
\text { dominant method of teaching } \\
\text { and learning of mathematics in } \\
\text { my institution. }\end{array}$ & $\begin{array}{r}31 \\
(51.7)\end{array}$ & $\begin{array}{r}18 \\
(30.0)\end{array}$ & $\begin{array}{r}11 \\
(18.3)\end{array}$ & 3.40 & 1.39 & .086 \\
\hline 16 & $\begin{array}{l}\text { Learning of mathematics } \\
\text { through the distance and online } \\
\text { mode is not efficient. }\end{array}$ & $\begin{array}{r}28 \\
(46.7)\end{array}$ & $\begin{array}{r}19 \\
(31.7)\end{array}$ & $\begin{array}{r}13 \\
(21.6)\end{array}$ & 3.20 & 1.27 & .243 \\
\hline
\end{tabular}

*Binomial test

In Table 2, items 12 to 14, $\mathrm{p}<.05$ suggested that access to efficient internet facilities, flexible teaching and learning, different forms of media, and access to mathematics tutors in ID cannot be underestimated. This provides support for Jimoh's (2013) view on the importance of variety of media in distance and online learning environment. The p>.05 in items 10 and 15 signified that the students have diverse experiences with ID. Whereas, the results in items 9, 11, and 16, p>.05 show the need for improvement in ID to remove frustration in learning mathematics and increase efficiency and enjoyment through this mode (Edu, Sule, \& Nsor, 2016).

\section{Emerging Issues from Qualitative Data}

Semi-structured interviews were conducted to collect qualitative data in this study. The aim was to give the interviewees (participants) the opportunity to elaborate on their experiences with ID in learning of 
undergraduate mathematics in Nigeria. The interviews were conducted with a sample of the students that completed the questionnaire from both DLI and NOUN. They were recorded with the permission of the students and transcribed word-for-word to generate narrative data. The participants' own words were used to bring out the understanding of ID in undergraduate mathematics.

The quantitative analysis results in Tables 1 and 2 described the general picture of the students' experiences with ID while the qualitative analysis provided deep understanding of their experiences and answers the third question in this paper. The emerging themes, sub-themes, and the categories are summarised in Figure 1.

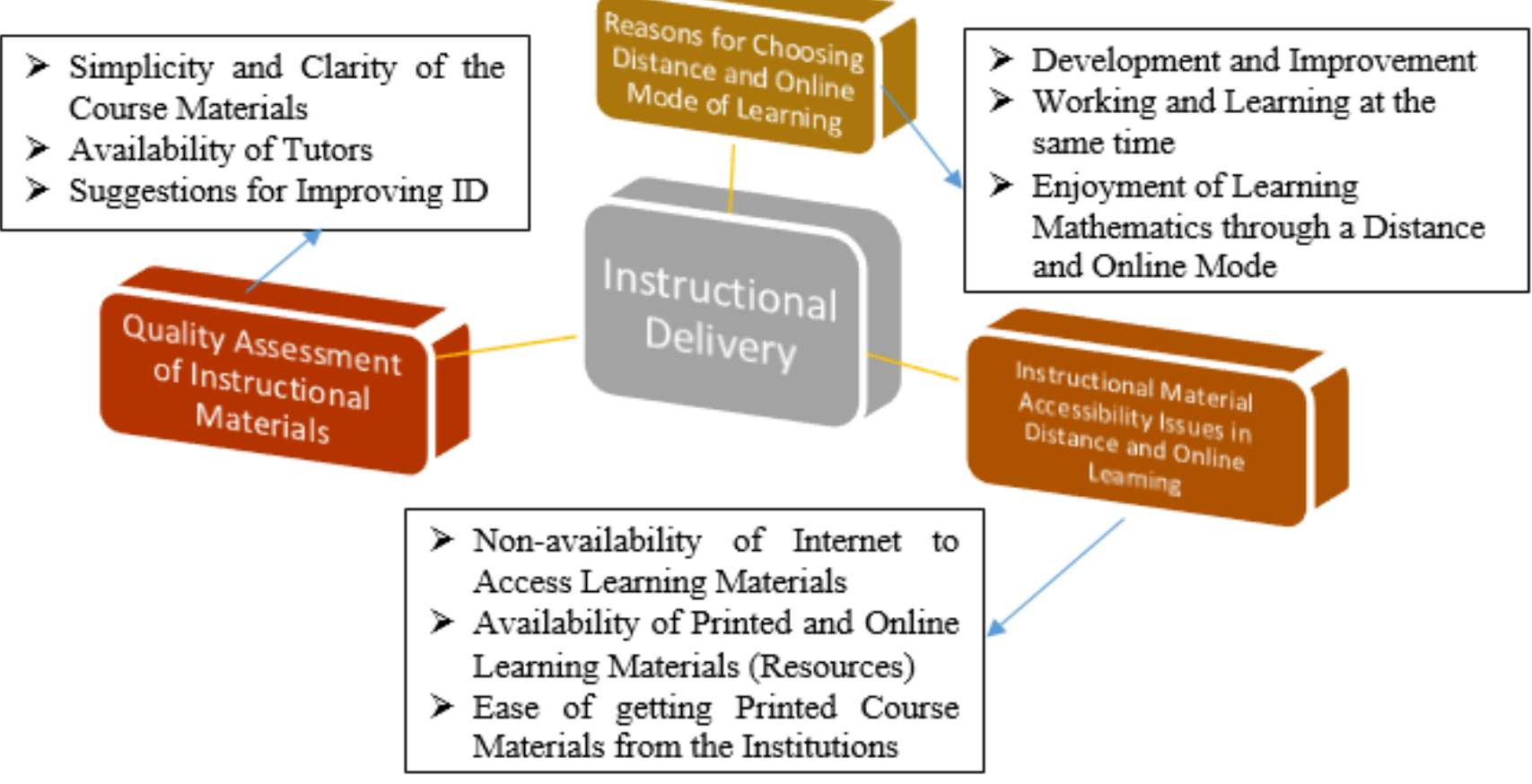

Figure 1. Outline of emerging themes, sub-themes, and categories.

The emerging categories from reasons for choosing a distance and online mode of learning revealed that the students' desire for career development and improvement necessitated their choice of studying through this mode. As one of the participants reflected, "(i)t gives room for somebody that is working to acquire knowledge, so that I will be going to school and also doing my work together." Despite the students pointing out experiences that hinder their enjoyment of the programme, which included not putting the right infrastructure in place, there seems to be some level of enjoyment among the students who were learning mathematics through this mode, as captured by a student: "I am enjoying the programme, it is just there are some difficulties here and there and this may be due to the new development going on in this school but maybe with time, they will improve."

The narratives of the students on the challenges they face in accessing learning materials through the Internet revealed that the universities provided little or no Internet facilities for the students and that many students were required to provide their own Internet access. A number of comments from the 
participants from the ODL institutions used for this study indicated the need for improvement in access to the Internet. One participant commented as follows: "Yea, I have my own personal access to [the] Internet [and] it's not from school," while another student stated: "No I provide internet on my own, [the] school did not provide [it] for me. Though sometimes, you might get [it] at the school e-library but it is not effective. I use my personal Internet to source and download learning materials online." These comments demonstrate the gap between the participants' expectations and service provisions received from the universities.

The results on available resources further suggest that the students are not entirely satisfied with the learning resources in their institutions. The points raised by the students were captured in the following statements:

There are [not] enough resources available for studying mathematics through this mode. Most [of the] time we work with other institutions, doing joint work, comparing and sourcing for materials where one can get. It is more like you the student [are] studying, sourcing and getting learning materials yourself.

The simplicity is there but not in all the modules, most [of our] mathematics modules [are not] simple [enough] for one to read and understand on his or her own.

No, the [course] materials are not simplified [or designed] enough to take care of the abstract nature of mathematics, except you can get [some] face-to-face ([assistance], asking question from the lecturer.

The majority of students interviewed in both institutions felt that mathematics resources were not available and also not simplified to mitigate the abstract nature of mathematics. Lack of access to mathematics resources may have led the students sourcing materials on their own, thereby encouraging the development of mathematical skills and widening intellectual ability in them.

The students also indicated that the process of obtaining the printed materials demands extra time due to long queues they experience. One of the participants had the following to say:

Just look at the queue right there [pointing at the direction where the course materials were being distributed], [the students] are queuing for course materials; the last time I queue for course materials was in 100 level [first year]. When you [visit the school to] queue for [the course materials you have already paid for], you [spend lots of] your money to come and queue for the materials whereas [at the end, you will not be able to get them], except you [visit the school website] online to download [the materials using] your personal Internet that is the only way you can [have access to] your course materials. Don't rely on the hardcopy [of the materials because] they [will not give them] to you, except you [can] go and buy because they sell outside there as well even after paying to the school for them.

Students learning in this mode seem to take responsibility for their own learning by supporting themselves. The students' narratives indicated availability of tutors in other subjects with very few or none in mathematics education courses. Interestingly, students' frustration regarding a lack of mathematics tutors for ID can be gleaned from the following comment: "Talking about the tutor, we don't have any, we can just forget about that because they are not available. But we talk among ourselves, 
we normally meet face-to-face, sometimes to discuss some topics." The students made a number of suggestions including the need to provide occasional face-to-face lectures to address their challenges with content, using different forms of media for teaching, providing learning resources, and availability of mathematics tutors for effective ID.

\section{Discussion}

The study revealed that most students chose to study through this mode due to work commitments, however, the lack of essential resources for complete course delivery may be affecting them negatively in their studies. Based on the results from quantitative and qualitative analyses, it appeared that even while the students may have access to learning materials over the Internet and through print (Garrett, 2016), the abstract nature of mathematics is not addressed adequately in the materials resulting in the content not being simplified enough to address the challenges.

This paper has shown that to further improve the students' experiences in ID for mathematics, access to helpful tutors is not only necessary but perhaps critical. The ELT emphasised that every learner produces "rules and mental patterns" they can use to make meaning of their experiences (Murphrey, 2010). This was specifically demonstrated (Table 1 , question 8 , and students' narratives) by how the students regulated their mental mind to adapt to new experiences in not giving up when there are challenges in understanding the learning materials and organising themselves to solve mathematical problems facing them. Noteworthy from this theory is the tutors' availability to facilitate and regulate learning instead of just giving out information. This expectation was, however, not fulfilled for many of the participants in this study, as expressed by the learners' comments above.

\section{Conclusion and Recommendations}

The ELT is a function of four aspects: concrete experiencing, reflective observation, abstract conceptualisation, and active experimentation (Kolb, 1984). As reflected in the results of our study, learners prefer receiving feedback from peers, while recognising the instructors as helpers. Thus the students relating among themselves and sourcing learning materials on their own as revealed in their narratives were the reflections of their concrete experiences. In support of reflective observation, learners who prefer acting and relating with all the available learning materials may be limited with a shortage of learning resources and a lack of mathematics tutors as reflected by the participants.

Abstract conceptualisation learners prefer working with symbols, while those with active experimentation are good at solving practical problems through group discussion. Therefore, lack of effective Internet connectivity and extra time required in getting printed mathematics course materials as reported by the participants suggest that abstract conceptualisation and active experimentation of Kolb's ELT are not supported in this study. Without doubt, this may adversely affect the students' conduct of systematic close examination in learning and development of ideas for solving mathematical problems. It can be concluded that a holistic model of the learning experience to empower students to manage and gain control of their learning is not totally evident in this study.

The results of this study provides evidence that well-designed course materials and instructor support are very important to the success of distance and online learning of undergraduate mathematics courses. This calls for an urgent need to improve the design, development, and provision of 
mathematics course materials and programmes for distance and online mathematics learning. The processes involved in this study were fundamental because they helped to clarify thoughts and to generate new insight into the ID of mathematics in Nigeria.

As a recommendation, further research is needed using, for example, specific mathematical topics to explore ID and student experiences of learning the topics through this mode. Students' dependence on printed materials suggest the need for mathematics course designers and developers to make the materials as simple as possible for the students to study and understand on their own. Finally, the regulatory agencies such as the National Universities Commission (NUC) in Nigeria should ensure and oversee the ID of mathematics at university-level to strengthen the understanding of the subject and its applications in sciences, engineering, and other courses that require mathematical literacy.

One limitation of this study lies in the sample of two ODL institutions in Nigeria. Even though these cohorts are fairly representative, students' experiences at other ODL institutions would enhance our understanding of the challenges and opportunities for studying mathematics through this mode. 


\section{References}

Ayo, C. K., Odukoya, J. A., \& Azeta, A. (2014). A review of open and distance education and human development in Nigeria. International Journal of Educational Technology, 9(6), 63-67.

Barker, M.A., Robinson, J.S., \& Kolb, D.A. (2012). Aligning Kolb's experiential learning theory with a comprehensive agricultural education model. Journal of Agricultural Education, 53(4), 1-16.

Bertini, L. F. (2016). The role of virtual tutors in distance education for primary teachers: Focusing on mathematics. Educação e Pesquisa, São Paulo, 42(1), 83-98.

Carver, R., King, R., Hannum, W., \& Fowler, B. (2007). Toward a model of experiential e-learning. MERLOT Journal of Online Learning and Teaching, 3(3), 247-256.

Commonwealth of Learning. (2005). Creating learning materials for open and distance learning: a handbook for authors and instructional designers. Vancouver, Canada: Commonwealth of Learning.

Creswell, J.W. (2014). Research design: Qualitative, quantitative and mixed methods approach (4th ed.). Los Angeles: Sage Publications.

Edu, M. I., Sule, S. A., \& Nsor, E. E. (2016). Open and distance learning (ODL) education in Nigeria: Challenges of academic quality. Journal of Educational Policy and Entrepreneurial Research (JEPER), 3(5), 22-32.

Elo, S. \& Kyngäs, H. (2008). The qualitative content analysis process. Journal of Advanced Nursing, 62(1), 107-115.

Federal Republic of Nigeria. (2004). National policy on education, Lagos, NERDC

Evrim, B., Correia, A., \& Thompson, A. (2011). Transforming online teaching practice: Critical analysis of the literature on the roles and competencies of online teachers. Distance Education, 32(3), 421-439.

Garrett, R. (2016). The state of open universities in the commonwealth: A perspective on performance, competition and innovation. Burnaby, Canada: Commonwealth of Learning

Harrington, R., \& Loffredo, D. A. (2010). MBTI personality type and other factors that relate to preference for online versus face-to-face instruction. Internet and Higher Education. 13, 8995.

Hathaway, K. L. (2014). An application of the seven principles of good practice to online courses. Research in Higher Education Journal, 22, 1-12. Retrieved from http://www.aabri.com/manuscripts/131676.pdf

Jimoh, M. (2013). An appraisal of open and distance learning programme in Nigeria. Journal of Education and Practice, 4(3), 1-8. 
Jones, S. J., \& Long, V. M. (2013). Learning equity between online and on-site mathematics courses. MERLOT Journal of Online Learning and Teaching, 9(1), 1-12.

Juan, A., Huertas, A., Steegmann, C., Corcoles, C., \& Serrat, C. (2008). Mathematical e-learning: State of the art and experiences at the open university of Catalonia. International Journal of Mathematical Education in Science and Technology, 39(4), 455-471.

Kolb, D. (1984). Experiential learning: Experience as the source of learning and development. Englewood Cliffs, NJ: Prentice Hall.

Kolb, D. A., Boyatzis, R. E., \& Mainemelis, C. (2000). Experiential learning theory: Previous research and new directions. In R. J. Sternberg \& L. F. Zhang (Eds.). Perspectives on cognitive, learning, and thinking styles (pp. 227-248). NJ: Lawrence Erlbaum.

Ku, H., Akarasriworn, C., Glassmeyer, D.M., Mendoza, B., \& Rice, L.A. (2011). Teaching an online graduate mathematics education course for in-service mathematics teachers. Quarterly Review of Distance Education, 12(2), 135-147.

Lee, J. (2014). An exploratory study of effective online learning: Assessing satisfaction levels of graduate students of mathematics education associated with human and design factors of an online course. The International Review of Research in Open and Distance Learning, 15(1), 111-132.

Mayes, R. (2011). Themes and strategies for transformative online instruction: A review of literature and practice. The Quarterly Review of Distance Education, 12(3), 151-166.

Murphrey, R. P. (2010). A case study of e-learning: Using technology to create and facilitate experiential learning. The Quarterly Review of Distance Education, 11(4), 211-221.

Ohene, J. B., \& Essuman, S. O. (2014). Challenges faced by distance education students of the University of Education, Winneba: Implications for strategic planning. Journal of Education and Training, 1(2), 156-176.

Osipita, O. (2016). Towards improving distance education in Nigeria with virtual technology. Interlink Continental Journal of Educational Research and General Studies, 2(1), 1-6.

Ramsden, P. (1991). A performance indicator of teaching quality in higher education: The course experience questionnaire. Studies in Higher Education, 16(2), 129-149.

Tapfumaneyi, K. D. K. (2013). The role of open and distance learning (ODL) in development in Africa. International Journal of Advanced Research, 1(5), 557-564.

Teddlie, C., \& Tashakkori, A. (2009). Foundations of mixed methods research. Thousand Oaks, CA: Sage Publications.

Vilardi, R., \& Rice, M. L. (2014). Mathematics achievement: Traditional instruction and technologyassisted course delivery methods. Journal of Interactive Online Learning, 13(1), 16-28. 
Young, S., \& Duncan, H. E. (2014). Online and face-to-face teaching: How do the students ratings differ? Journal of Online Learning and Teaching, 1O(1), 70-79.

Yushau, B., \& Khan, M. A. (2014). Student perceptions of online homework in preparatory year precalculus courses. International Journal of Mathematics Trends and Technology, 8(1), 12-17.

i This paper is based on my Doctorate research work from University of the Free State, Bloemfontein, South Africa

Athabasca

University

(2) 9 